\title{
Quality characteristics of barley Makgeolli prepared with different barley cultivars and milling recovery
}

\author{
Kyung Ha Lee, Seuk Ki Lee, Hye-Young Park, Eun-Yeong Sim, Koan Sik Woo, \\ Sea-Kwan Oh, Byoungkyu Lee, Hyun-Joo Kim* \\ Crop Post-harvest Technology Division, Department of Central Area Crop Science, National Institute of Crop Science, \\ RDA, Suwon 16613, Korea
}

\section{보리의 품종 및 도정률에 따른 막걸리의 품질특성평가}

\author{
이경하·이석기 · 박혜영 · 심은영 · 우관식 · 오세관 · 이병규·김현주* \\ 농촌진흥청 국립식량과학원 중부작물부 수확후이용과
}

\begin{abstract}
The purpose of this study was to evaluate the effects of barley cultivars (Saessalbori, Saechalssalbori and Huinchalssalbori) and different milling recovery $(95 \%, 85 \%$ and $75 \%$ on quality characteristics of barley Makgeolli. The content of moisture, ash, crude protein, and crude fat in barley seeds were reduced with decreasing milling recovery. The qualities of barley Makgeolli were also significantly affected by the milling recovery. Decreasing milling recovery of all cultivars resulted to increase in total sugar content and reducing sugar content but decrease in $\mathrm{pH}$ while alcohol content and total acidity were not significantly affected. Moreover, the lightness and yellowness of barley Makgeolli increased by milling while its redness decreased. The sensory evaluation showed that the consumer preference for barley Makgeolli increased at the lowest milling recovery (75\%). The results of this study suggest that the milling recovery and cultivar of barley were important factors to improve the taste and color of barley Makgeolli.
\end{abstract}

Key words : barley, cultivar, milling recovery, Makgeolli

\section{서 론}

우리 식생활에서 보리(Hordeum vulgare L.)는 쌀과 더불 어 오랫동안 주식으로서 중요한 비중을 차지하고 있으며, 주로 혼반용으로 사용되고 있다. 보리의 영양성분은 쌀과 비교하여 당질이 $77 \%$ 로 다소 낮은 반면, 콜레스테롤 저하 효과와 관련된 식이섬유는 밀가루의 5 배, 쌀의 16 배에 달하 고 한국인들에게 부족하기 쉬운 칼슘과 철은 각각 8 배, 5 배 수준이다(1). 보리를 알곡 형태로 식용하기 위해서 도정을 하게 되며 도정은 정맥을 얻기 위하여 종피, 호분층, 외부

*Corresponding author. E-mail : tlrtod@korea.kr Phone : 82-31-695-0614, Fax : 82-31-695-4085

Received 28 June 2016; Revised 11 July 2016; Accepted 12 July 2016.

Copyright (c) The Korean Society of Food Preservation. All rights reserved.
배유부 및 배아를 점차적으로 제거하는 연삭처리 공정으로 가공을 위한 필수과정이다(2). 보리는 이러한 도정과정을 거쳐 가루로 만들어져 밀가루에 대체 가능한 복합분 형태로 빵류, 과자류, 면류 및 스낵류 등의 제품에 이용되고 있다.

막걸리는 찹쌀, 멥쌀, 보리쌀, 현미, 옥수수, 고구마, 밀 등의 전분질을 원료로 하고 발효제로서 누룩을 첨가하여 복발효시켜 술덧을 혼탁하게 제성한 우리나라 고유의 전통 주로 단맛, 신맛, 쓴맛, 매운맛과 청량감이 있는 알코올 함량 이 약 6\% 정도의 술이다(3-5). 최근 막걸리 제조 시 영양이 나 기능성 증진을 위해 고구마, 수수, 조, 찹쌀, 팥, 현미, 흑미 등의 전분원료와, 감, 블루베리, 석류, 크렌베리 등의 과실을 이용한 막걸리 제조 연구가 활발히 수행되고 있으나 쌀과 함께 대표적으로 식량자원으로 알려진 보리를 활용한 막걸리 제조는 미진한 수준이다(6). 또한 원료곡 도정률에 따른 주류 가공연구 $(7,8)$ 는 대부분 쌀 중심으로 발표되고 있다. $\mathrm{Kim}$ 등(9)의 보고에 따르면 도정률이 감소함에 따라 
지방 및 회분 함량이 크게 감소하고 쌀가루의 물 결합능력, 팽윤력과 용해도는 증가하는 반면에 아밀로그램에서 초기 호화온도는 낮아지고 최고 점도가 높아진다고 하였다(10). 또한 $\mathrm{Kim}$ 등(11)은 도정률 감소에 따른 찹쌀발효주 발효 시 알코올 함량은 감소하고 환원당은 증가한다고 하였다. 따라서 본 연구에서는 우리나라 전통주인 막걸리 양조에 국산 보리의 이용 가능성을 알아보기 위한 기초연구의 일환 으로 보리 도정률이 막걸리 품질특성에 미치는 영향을 살펴 보기 위해 도정률을 달리한 새쌀보리, 새찰쌀보리 및 흰찰 쌀보리 원료의 특성을 살펴보고 이를 이용하여 제조한 막걸 리의 품질특성을 분석하였다.

\section{재료 및 방법}

\section{실험재료}

본 연구에 사용된 보리는 새쌀보리(Saessalbori, Yeonggwang, Korea), 새찰쌀보리(Saechalssalbori, Yeonggwang, Korea) 및 흰찰쌀보리(Huinchalssalbori, Gunsan, Korea)를 이용하 였으며, 2014년에 재배된 작물을 수확하여 사용하였다. 막 걸리 제조를 위한 발효제인 입국은 천일산업(Cheonil Co., Yeosu, Korea)에서 구입하여 사용하였고, 누룩은 국산 밀로 제조한 재래누룩(Nuruk, Jinjugokja, Jinju, Korea), 효모는 Saccharomyces cerevisiae(La Parisienne, Societe Industrielle Lesaffre, Marcq en Baroeul, France)를 구입하여 사용하였 다.

\section{원료 도정}

본 연구에 사용한 보리는 도정기(Barley mill DK 108, Dongyang Techtool Co., Daegu, Korea)를 이용하였으며, 도 정 전후의 무게 차이로 계산된 도정률(Milling recovery, 정 맥중량에 대한 보리의 중량비율)은 새쌀보리, 새찰쌀보리 및 흰찰쌀보리 각각 $95 \%, 85 \%$ 및 $75 \%$ 로 실험에 사용하였 다.

\section{원료곡의 품질 특성}

\section{일반성분 분석}

도정률을 달리한 보리 원료곡의 수분함량은 적외선 수분 측정기(Moisture analyzer MOC63u, Shimadzu Co., Kyoto, Japan)를 이용하여 측정하였고, Park 등(6)의 방법에 따라 조회분, 조단백질, 조지방 및 탄수화물 함량을 측정하였다. 즉, 조회분은 $600^{\circ} \mathrm{C}$ 에서 직접회화법으로 회화 후 측정하였 고, 조단백질은 semimicro-Kjeldahl법으로 자동 단백질 분 석기(Kjeltec 2400 AUT, Foss Tecator, Mulgrave, Australia) 로 분석하였으며, 조지방은 Soxhlet 추출기(Soxtec System HT 1043 extraction unit, Foss Tecator, Hoganas, Sweden)를 사용하여 diethyl ether로 추출하여 정량하였다. 탄수화물은
시료 $100 \mathrm{~g}$ 에 수분, 조지방, 조단백질, 조회분 값을 감하여 산출하였다

\section{Rapid Visco Analyze}

보리 품종 및 도정률별 아밀로그램 특성은 $\mathrm{Kim}$ 등(12)의 방법을 토대로 신속점도측정계(Rapid Visco Analyzer, Model RVA-3D, Newport Scientific, Warriewood, Australia) 를 이용하여 측정하였다. 즉, 시료를 $60 \mathrm{mesh}$ 이상으로 분쇄 한 후 $3 \mathrm{~g}$ 을 칭량하여 알루미늄 캔 용기에 투입하고 25 $\mathrm{mL}$ 의 증류수에 분산시켜 $50^{\circ} \mathrm{C}$ 에서 1 분간 유지시킨 후 $50^{\circ} \mathrm{C}$ 에서 $95^{\circ} \mathrm{C}$ 까지 4.7 분 동안 상승시키고 $95^{\circ} \mathrm{C}$ 에서 2.5 분간 유지시켰다. 그 후, 다시 3.7 분 동안에 $50^{\circ} \mathrm{C}$ 로 냉각시키면서 점도 특성을 조사하였다. 총 실험 시간은 약 13 분이며 실험 후 초기 호화 온도(pasting temperature), 최고점도(peak viscosity), 최저점도(trough), 최종점도(final viscosity), 강하 점도(breakdown) 및 치반점도(setback)를 계산하여 특성을 비교하였다.

\section{보리 품종 및 도정률에 따른 막걸리 제조 및 품질 특성 평가}

\section{막걸리 제조}

보리 품종 및 도정률에 따라 제조한 막걸리의 품질 특성 을 비교하기 위하여 보리를 수세한 다음 3 배 부피의 물에 3 시간 동안 침지 후 1 시간 동안 물빼기를 하였다. $100^{\circ} \mathrm{C}$ 에서 1 시간 동안 증자한 다음 식힌 후 생 원료 무게 대비하여 입국 $20 \%(\mathrm{w} / \mathrm{w})$, 재래누룩 $1 \%(\mathrm{w} / \mathrm{w})$, 가수량 $180 \%(\mathrm{w} / \mathrm{w})$, 효모는 생 원료와 물 첨가량을 합한 양의 $0.05 \%(\mathrm{w} / \mathrm{w})$ 를 첨가하였다. 원료를 혼합한 다음 $25^{\circ} \mathrm{C}$ 발효실에서 7 일간 발효시켰으며 발효 3 일차까지 1 일 1 회 술덧을 고루 저어 섞어주었고 7 일차에 거르기 한 후 거른 여액을 시료액으로 분석하였다.

\section{가용성 고형분 및 알코올 함량 측정}

가용성 고형분 함량은 시료액을 취하여 당도계(PAL-3, ATAGO, Tokyo, Japan)를 이용하여 분석하였다. 알코올 함 량은 시료액 $100 \mathrm{~mL}$ 에 증류수 $100 \mathrm{~mL}$ 를 혼합하여 증류하 였다. 증류액 약 $90 \mathrm{~mL}$ 를 받고 증류수로 $100 \mathrm{~mL}$ 로 정용한 후, $15^{\circ} \mathrm{C}$ 로 조정한 다음 주정계를 이용하여 알코올 함량을 측정하였다(14).

\section{색도 측정}

보리의 품종 및 도정률에 따라 제조한 막걸리의 색도변 화를 측정하기 위해 시료를 $50 \mathrm{~mm}$ 의 투명용기에 옮겨 담은 후 Color Differencemeter(CM-3500d, Konica Minolta Sensing, Osaka, Japan)를 이용하여 측정하였다. 기계는 측 정 전 표준흑판과 표준백판을 표준화한 후 사용하였으며 명도( $\mathrm{L}^{*}$, lightness), 적색도 $\left(\mathrm{a}^{*}, \mathrm{redness}\right)$ 및 황색도 $\left(\mathrm{b}^{*}\right.$, 
yellowness)값으로 나타내었다. 측정된 값은 Spectra Magic Software(Minolta Cyber Chrom Inc., Osaka, Japan)를 이용하 여 기록하였다.

\section{$\mathrm{pH}$ 및 총산 측정}

$\mathrm{pH}$ 는 $\mathrm{pH}$ meter(Model 750; iSTEC, Seoul, Korea)로 측정 하였고, 총산은 시료 $10 \mathrm{~mL}$ 에 $0.1 \mathrm{~N} \mathrm{NaOH}(\mathrm{F}=1.000)$ 용액을 넣어 $\mathrm{pH}$ 8.2가 될 때까지 소비된 $\mathrm{NaOH}$ 의 용량 $(\mathrm{mL})$ 을 측정 하여 젖산(lactic acid) 함량으로 환산하였다.

\section{환원당 측정}

품종 및 도정률에 따른 보리 막걸리의 환원당 함량은 dinitrosalicylic acid(DNS) 법(15)을 변형하여 측정하였다. 즉, 시료 $1 \mathrm{~mL}$ 에 DNS용액 $3 \mathrm{~mL}$ 를 혼합한 후 5 분 동안 중탕 가열하고 냉각한 후 분광광도계(UV Spectrophotometer 1601, Shimadzu Co., Kyoto, Japan)를 이용하여 $550 \mathrm{~nm}$ 에서 흡광도를 측정하였다. 보리 원료곡의 환원당 함량을 비교 하기 위하여 시료 $10 \mathrm{~g}$ 에 증류수를 $90 \mathrm{~mL}$ 가한 다음 1 시간 동안 교반 추출하여 여과한 액을 시료로 사용하였다. 이때 당 정량은 glucose를 표준물질로 사용하여 상기의 방법으로 측정된 표준곡선으로부터 환산하였다.

\section{관능평가}

제조된 막걸리의 기호도 검사를 위해 관능평가에 대한 사전 교육을 받은 20 명을 패널로 선정하여 기호도 검사를 실시하였다. $4^{\circ} \mathrm{C}$ 에서 0 일간 숙성시킨 막걸리의 색, 맛, 향, 전체적 기호도를 7점 척도법(7:가장 좋다, 1:가장 싫다)으로 평가하여 점수를 표시하였다. 시료는 난수표로 표기되어 투명 플라스틱 컵에 제공하였고 검사원은 무작위로 제공된
시료를 평가하였다.

\section{통계처리}

본 실험에서 얻어진 결과는 SPSS program 12.0(SPSS Inc. Chicago, IL, USA)을 이용하여 분석하였으며, 각 실험구간 차이는 $\mathrm{p}<0.05$ 수준에서 one-way ANOVA를 실시하였으 며, Duncan's multiple range test로 유의성을 검증하였다.

\section{결과 및 고찰}

\section{보리 품종 및 도정률에 따른 원료곡의 품질 특성 \\ 일반성분}

보리의 품종과 도정률에 따른 수분, 조단백질, 조지방, 조회분 및 탄수화물 함량을 분석한 결과 새쌀보리의 수분함 량과 흰찰쌀보리의 조지방 함량을 제외한 모든 항목에서 도정률이 감소함에 따라 각 성분의 함량이 감소하였다 (Table 1). 즉, 도정률이 $95 \%, 85 \%, 75 \%$ 로 감소함에 따라 새쌀보리, 새찰쌀보리, 흰찰쌀보리의 조회분 함량은 각각 28.22 46.01, 17.80 35.59, 23.81 38.89\% 감소하였으며, 조 단백질 함량은 각각 1.82 10.36, 7.75 13.09, 4.82 12.36\% 감소하였다. 조지방 함량의 경우 새쌀보리 및 새찰쌀보리 는 39.60 50.00\% 및 9.41 45.05\% 감소하였으며, 흰찰쌀보 리는 도정률이 감소함에 따라 조지방 함량이 높게 나왔으나 유의적 차이는 없었다. 반면 모든 항목에서 도정률 감소에 따라 탄수화물 함량은 유의적으로 증가하였다.

이러한 결과는 $\operatorname{Kim}$ 등(9)의 도정률에 따른 백미와 미강 의 원료곡의 일반 성분변화와 같은 경향을 보였다. Park 등(6)은 원료의 도정에 따라 외피와 호분층이 제거되면서

Table 1. Proximate composition of different from barley cultivars with different milling recovery

\begin{tabular}{|c|c|c|c|c|c|c|}
\hline Barley variety & Milling recovery & Moisture & Ash & Protein & Fat & Carbohydrate \\
\hline \multirow{4}{*}{$\begin{array}{l}\text { Saessal } \\
\text { bori }\end{array}$} & 95 & $10.49 \pm 0.05^{\mathrm{b2})}$ & $1.63 \pm 0.26^{\mathrm{a}}$ & $8.78 \pm 0.16^{\mathrm{a}}$ & $2.02 \pm 0.20^{\mathrm{a}}$ & $77.08 \pm 0.55^{\mathrm{c}}$ \\
\hline & 85 & $10.92 \pm 0.10^{\mathrm{a}}$ & $1.17 \pm 0.15^{b}$ & $8.62 \pm 0.28^{\mathrm{a}}$ & $1.22 \pm 0.08^{b}$ & $78.07 \pm 0.51^{b}$ \\
\hline & 75 & $10.30 \pm 0.06^{c}$ & $0.88 \pm 0.05^{\mathrm{c}}$ & $7.87 \pm 0.11^{\mathrm{b}}$ & $1.01 \pm 0.04^{b}$ & $79.94 \pm 0.14^{\mathrm{a}}$ \\
\hline & $\mathrm{SEM}^{1)}$ & 0.07 & 0.14 & 0.16 & 0.10 & 0.36 \\
\hline \multirow{4}{*}{$\begin{array}{c}\text { Saechalssal } \\
\text { bori }\end{array}$} & 95 & $10.78 \pm 0.19^{\mathrm{a}}$ & $1.18 \pm 0.07^{\mathrm{a}}$ & $9.93 \pm 0.10^{\mathrm{a}}$ & $2.02 \pm 0.09^{\mathrm{a}}$ & $76.09 \pm 0.30^{c}$ \\
\hline & 85 & $10.84 \pm 0.13^{\mathrm{a}}$ & $0.97 \pm 0.06^{b}$ & $9.16 \pm 0.19^{b}$ & $1.83 \pm 0.06^{b}$ & $77.19 \pm 0.44^{b}$ \\
\hline & 75 & $10.23 \pm 0.06^{b}$ & $0.76 \pm 0.02^{\mathrm{c}}$ & $8.63 \pm 0.20^{c}$ & $1.11 \pm 0.04^{\mathrm{c}}$ & $79.27 \pm 0.23^{\mathrm{a}}$ \\
\hline & SEM & 0.13 & 0.05 & 0.14 & 0.05 & 0.27 \\
\hline \multirow{4}{*}{$\begin{array}{c}\text { Huinchalssal } \\
\text { bori }\end{array}$} & 95 & $12.08 \pm 0.18^{\mathrm{a}}$ & $1.26 \pm 0.21^{\mathrm{a}}$ & $9.55 \pm 0.31^{\mathrm{a}}$ & $1.49 \pm 0.17$ & $75.62 \pm 0.77^{b}$ \\
\hline & 85 & $12.00 \pm 0.37^{\mathrm{a}}$ & $0.96 \pm 0.05^{b}$ & $9.09 \pm 0.42^{\mathrm{a}}$ & $1.50 \pm 0.06$ & $76.46 \pm 0.35^{b}$ \\
\hline & 75 & $11.22 \pm 0.02^{b}$ & $0.77 \pm 0.05^{b}$ & $8.37 \pm 0.08^{b}$ & $1.62 \pm 0.07$ & $78.02 \pm 0.17^{\mathrm{a}}$ \\
\hline & SEM & 0.20 & 0.11 & 0.25 & 0.09 & 0.41 \\
\hline
\end{tabular}

\footnotetext{
${ }^{1)}$ Standard error of the means $(n=9)$.
}

${ }^{2) a-c}$ Values with different letters within the same column differ significantly $(p<0.05)$. 
여기에 포함되어 있는 단백질, 지방 등이 함께 제거되고 상대적으로 내부 전분층의 비율이 높아지면서 도정률이 감소함에 따라 유의적 차이를 나타냈다고 보고하였다.

\section{전분의 호화특성(RVA)}

보리의 도정률에 따른 호화특성 분석결과를 Fig. 1 에 제 시하였다. 전반적으로 최고점도, 최저점도, 강하점도 및 최 종점도가 도정률 감소에 따라 증가하는 경향을 나타냈다.

최고점도는 새쌀보리 및 흰찰쌀보리가 $281.94 \pm 6.65$ $387.26 \pm 3.51$ 및 293.29 $\pm 4.23 \sim 352.09 \pm 6.04 \mathrm{RVU}$ 로서 새찰쌀 보리 $107.80 \pm 3.83 \sim 246.18 \pm 0.83 \mathrm{RVU}$ 보다 유의적으로 높은 값을 나타내었다. 최종점도는 가열이 중지되고 냉각하는 단계에서 일어나는 과정으로서 아밀로스와 같은 전분 분자 들이 다시 재결합하여 점도가 증가(12)하는 단계로서 새찰 쌀보리에서 전반적으로 낮은 특성을 보였다. 치반점도는 최종점도와 최고점도의 차이를 나타내는 것으로서 전분의 노화와 관련이 있으며 값이 높을수록 노화진행 속도가 빠르 다는 것을 나타낸다. 본 연구에서는 흰찰쌀보리 도정률( 95 , 85 및 75\%)과 도정률 $75 \%$ 인 새쌀보리에서 치반점도 값이 가장 낮은 것으로 나타나 노화진행속도가 다른 시료군에 비해 낮을 것으로 판단된다. 일반적으로 호화 특성 측정 결과 최고점도와 강하점도가 높고 치반점도가 낮으면 식미 특성이 양호하게 되는데(13) 본 연구에서는 새쌀보리 및 흰찰쌀보리가 새찰쌀보리에 비해 식미특성이 양호할 것으 로 사료되며, 각 품종 모두 도정률이 낮을수록 식미가 양호 할 것으로 사료된다.

\section{보리 품종 및 도정률에 따라 제조한 막걸리의 품질 특성 평가}

가용성 고형분 및 알코올 함량 측정

가용성 고형분 함량은 막걸리의 향기와 단맛에 영향을 주는 주요 성분이며, 막걸리의 전분질 원료는 당화효소에 의해 당분으로 분해됨과 동시에 효모의 영양원이나 발효 기질로 이용되므로 효모의 에탄올 생산을 결정짓는 요인이 기도하다 $(14,15)$. 본 연구결과 가용성 고형분 함량은 도정 률이 감소함에 따라 유의적으로 증가하는 경향을 나타내었 다(Table 2). Park 등(16)은 누룩 생산 과정 중 발효에 관여하 는 미생물 중 곰팡이에 의해 생성되는 전분 분해효소 $a$ -amylase와 glucoamylase의 활성이 가용성 고형분 함량을 빠르게 증가시켰다고 보고하였다.

보리 도정률에 따른 막걸리의 알코올 함량은 새쌀보리가 $13.53 \pm 0.12 \sim 13.80 \pm 0.20 \%$, 새찰쌀보리가 $13.47 \pm 0.31 \sim 13.73$ $\pm 0.23 \%$, 흰찰쌀보리가 $13.90 \pm 0.17 \sim 14.07 \pm 0.12 \%$ 였고 도정 률에 따른 차이는 없었다(Table 4). Lee 등(5)은 국세청 주류 분석 교본에 따르면 알코올 함량은 막걸리의 보존과 향미에 영향을 주는 중요한 성분으로 알코올 함량 10 14\% 정도가 수율 및 품질 면에서 적당하다고 하여, 본 연구에서 제조된
보리막걸리는 적합한 알코올 함량을 함유한 것으로 나타 났다.

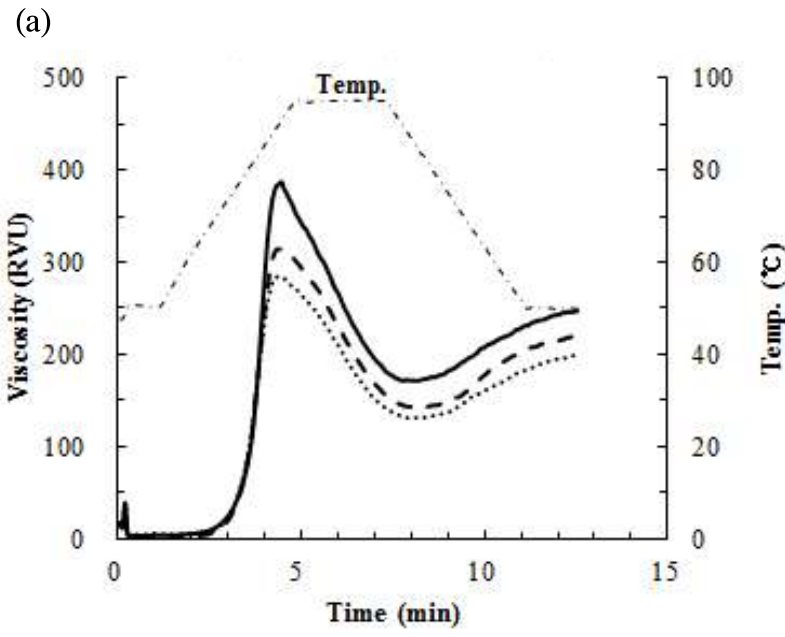

(b)

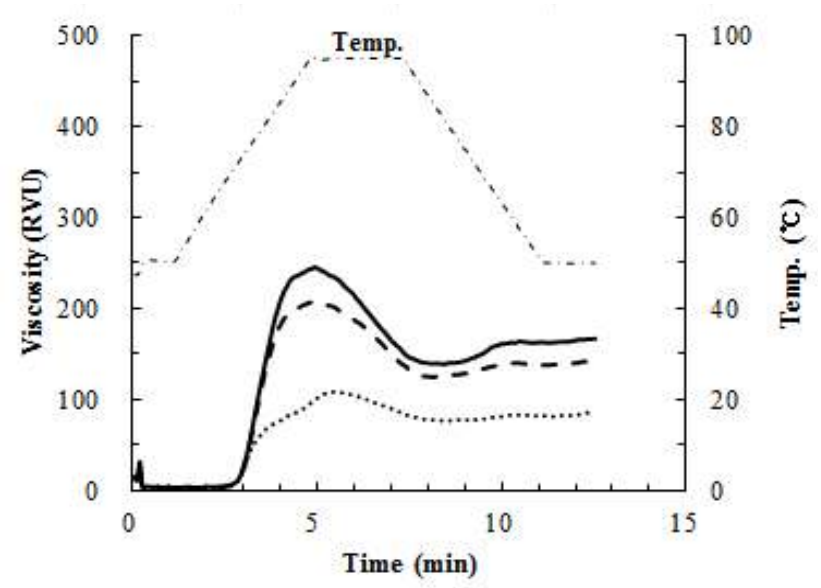

(c)

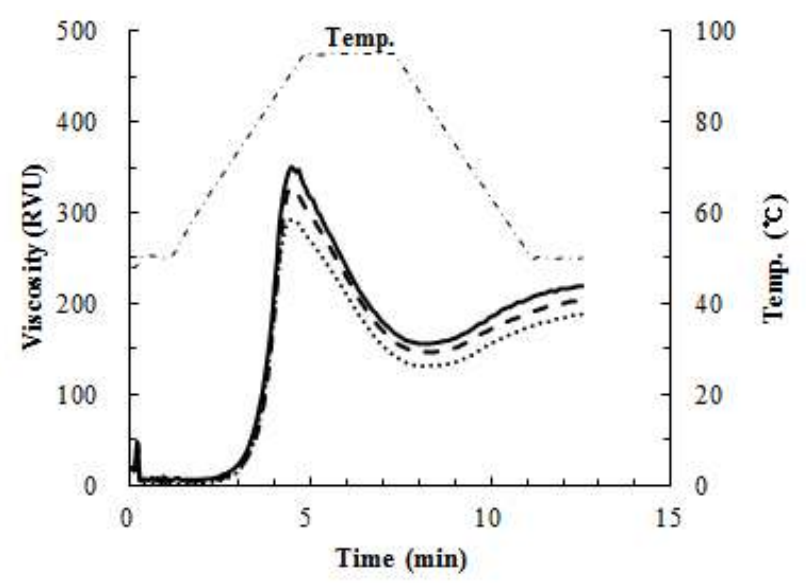

Fig. 1. Pasting characteristics of different barley cultivars with different milling recovery.

(a), Saessalbori, (b), Saechalssalbori, (c), Huinchalssalbori. $75 \%$; _...-, $85 \% ; \ldots \ldots \ldots \ldots . . . ., 95 \%$. 
Table 2. Total sugar and alcohol contents of Makgeolli brewed from different barley cultivars with different milling recovery

\begin{tabular}{cccc}
\hline Barley variety & $\begin{array}{c}\text { Milling recovery } \\
(\%)\end{array}$ & $\begin{array}{c}\text { Total sugar content } \\
\left({ }^{\circ} \text { Brix }\right)\end{array}$ & $\begin{array}{c}\text { Alcohol } \\
\text { content }(\%)\end{array}$ \\
\hline \multirow{3}{*}{ Saessalbori } & 95 & $9.72 \pm 0.05^{\mathrm{b} 2)}$ & $13.53 \pm 0.12$ \\
& 85 & $10.12 \pm 0.04^{\mathrm{a}}$ & $13.80 \pm 0.20$ \\
& 75 & $10.11 \pm 0.07^{\mathrm{a}}$ & $13.57 \pm 0.06$ \\
SEM ${ }^{1)}$ & 0.05 & 0.11 \\
\hline \multirow{3}{*}{ Saechalssalbori } & 95 & $9.34 \pm 0.05^{\mathrm{c}}$ & $13.47 \pm 0.31$ \\
& 85 & $9.69 \mathrm{~b} \pm 0.07$ & $13.73 \pm 0.23$ \\
& 75 & $9.97 \pm 0.09^{\mathrm{a}}$ & $13.68 \pm 0.25$ \\
& SEM & 0.06 & 0.22 \\
\hline Huinchalssalbori & 95 & $9.92 \pm 0.04^{\mathrm{b}}$ & $13.90 \pm 0.17$ \\
& 85 & $9.98 \pm 0.02$ & $14.07 \pm 0.12$ \\
& 75 & $10.29 \pm 0.05^{\mathrm{a}}$ & $13.93 \pm 0.12$ \\
& SEM & 0.03 & 0.01 \\
\hline
\end{tabular}

${ }^{1)}$ Standard error of the means $(\mathrm{n}=9)$.

${ }^{2) a-c}$ Values with different letters within the same column differ significantly $(p<0.05)$

\section{색도 측정}

보리 품종 및 도정률에 따라 제조한 막걸리의 색도 측정 결과 도정률에 따라 새쌀보리와 새찰쌀보리에서 명도는 증가하였으나 흰찰쌀보리에서는 감소하였다. 모든 시료에 서 도정률이 감소할수록 적색도는 감소하였으며, 황색도는 증가하는 경향을 보였다(Table 3). 하지만, 보리 원료의 품 종 및 도정률에 따른 색도 측정 결과 명도 적색도 및 황색도 모두 도정률에 따라 감소한 것으로 나타났다(data not shown)

Table 3. Hunter color value of raw material and Makgeolli brewed from different barley cultivars with different milling recovery

\begin{tabular}{ccccc}
\hline Barley variety & $\begin{array}{c}\text { Milling } \\
\text { recovery (\%) }\end{array}$ & $\mathrm{L}^{*}$ & $\mathrm{a}^{*}$ & $\mathrm{~b}^{*}$ \\
\hline \multirow{5}{*}{ Saessalbori } & 95 & $21.78 \pm 2.08^{\mathrm{b} 2)}$ & $14.66 \pm 0.39^{\mathrm{a}}$ & $33.84 \pm 1.48^{\mathrm{b}}$ \\
& 85 & $29.93 \pm 2.26^{\mathrm{a}}$ & $12.34 \pm 1.00^{\mathrm{b}}$ & $40.90 \pm 0.17^{\mathrm{a}}$ \\
& 75 & $30.16 \pm 2.08^{\mathrm{a}}$ & $12.28 \pm 0.85^{\mathrm{b}}$ & $41.06 \pm 0.56^{\mathrm{a}}$ \\
& SEM $^{\mathrm{1})}$ & 1.57 & 0.65 & 0.75 \\
\hline \multirow{5}{*}{ Saechalssalbori } & 95 & $21.92 \pm 1.39^{\mathrm{b}}$ & $14.16 \pm 0.40^{\mathrm{a}}$ & $32.22 \pm 1.19^{\mathrm{b}}$ \\
& 85 & $26.27 \pm 0.51^{\mathrm{a}}$ & $12.77 \pm 0.22^{\mathrm{b}}$ & $36.96 \pm 0.31^{\mathrm{a}}$ \\
& 75 & $27.47 \pm 0.51^{\mathrm{a}}$ & $12.69 \pm 0.23^{\mathrm{b}}$ & $37.95 \pm 0.19^{\mathrm{a}}$ \\
& SEM & 0.74 & 0.24 & 0.59 \\
\hline \multirow{3}{*}{ Huinchalssalbori } & 95 & $20.85 \pm 0.40^{\mathrm{b}}$ & $15.38 \pm 0.36^{\mathrm{a}}$ & $31.64 \pm 1.31^{\mathrm{c}}$ \\
& 85 & $28.85 \pm 3.06^{\mathrm{a}}$ & $12.98 \pm 1.27^{\mathrm{b}}$ & $38.85 \pm 0.64^{\mathrm{b}}$ \\
& 75 & $29.79 \pm 1.26^{\mathrm{a}}$ & $12.67 \pm 0.18^{\mathrm{b}}$ & $40.81 \pm 0.32^{\mathrm{a}}$ \\
& SEM & 1.57 & 0.63 & 0.70 \\
\hline
\end{tabular}

${ }^{1)}$ Standard error of the means $(\mathrm{n}=9)$.

${ }^{2) a-c}$ Values with different letters within the same column differ significantly $(\mathrm{p}<0.05)$
Chun 등(8)의 연구에서 쌀의 도정률에 따라 소곡주를 제조하였을 때 도정률이 증가할수록 명도는 증가하였으며 적색도 및 황색도는 감소하는 경향을 나타내었다고 하여 본 연구 결과와 차이를 보였다. 또한 Lee 등(7)은 쌀의 도정 률을 달리한 막걸리의 색도 값은 도정률에 영향을 받지 않았다고 발표한 바 있다. 따라서 막걸리의 원료 도정률 뿐만 아니라 부재료와의 혼합 및 발효 과정 등에서 막걸리 의 색도 변화가 있는 것으로 판단된다.

\section{$\mathrm{pH}$ 및 총산 측정}

$\mathrm{pH}$ 는 막걸리의 발효과정에서 생성되는 다양한 유기산의 종류와 농도 등에 영향을 받으므로 발효 진행 상황을 예측 할 수 있는 중요한 지표이다(17). 발효과정에서 생성되는 유기산, 탄산가스 및 기타 산 물질은 $\mathrm{pH}$ 에 영향을 미친다. $\mathrm{pH}$ 는 발효진행 상황과 알코올 생성정도를 짐작할 수 있는 중요한 지표가 된다.

본 연구결과에 따르면 도정률이 감소할수록 $\mathrm{pH}$ 가 유의 적으로 감소하는 경향을 나타내었다(Table 4). 이는 도정률 이 높을수록 술덧에 생육하는 미생물에 의해 유기산 등의 생성이 빠르게 진행되기 때문에 $\mathrm{pH}$ 가 급격히 저하된 것으 로 사료된다(18). 본 연구 결과 $\mathrm{pH}$ 범위는 3.82 4.12로 나타 내었으며 Baek 등(19)의 보고에 따르면 보통 막걸리의 $\mathrm{pH}$ 는 발효 초기에는 6.9 정도이며 발효 후에는 4.0 4.6범위로 발표하였고, Lee 등(20)은 주세법상 탁주의 $\mathrm{pH}$ 범위는 3.8 4.7 이라고 하여 본 연구결과는 적합한 탁주의 $\mathrm{pH}$ 범위 를 나타냈다.

보리 막걸리의 총산도는 새쌀보리가 $0.61 \pm 0.04 ~ 0.64 \pm$ $0.01 \%$, 새찰쌀보리가 $0.64 \pm 0.02 \sim 0.65 \pm 0.01 \%$, 흰 찰쌀보리

Table 4. $\mathrm{pH}$ and total acidity of Makgeolli brewed from different barley cultivars with different milling recovery

\begin{tabular}{cccc}
\hline Barley variety & $\begin{array}{c}\text { Milling } \\
\text { recovery }(\%)\end{array}$ & $\mathrm{pH}$ & $\begin{array}{c}\text { Total acidity } \\
(\%, \text { lactic acid base })\end{array}$ \\
\hline \multirow{3}{*}{ Saessalbori } & 95 & $4.12 \pm 0.02^{\mathrm{a} 2)}$ & $0.64 \pm 0.01$ \\
& 85 & $3.90 \pm 0.02^{\mathrm{b}}$ & $0.62 \pm 0.03$ \\
& 75 & $3.82 \pm 0.01^{\mathrm{c}}$ & $0.61 \pm 0.04$ \\
& SEM $^{\mathrm{l}}$ & 0.02 & 0.02 \\
\hline \multirow{5}{*}{ Saechalssalbori } & 95 & $4.07 \pm 0.01^{\mathrm{a}}$ & $0.65 \pm 0.02$ \\
& 85 & $3.92 \pm 0.01^{\mathrm{b}}$ & $0.65 \pm 0.01$ \\
& 75 & $3.85 \pm 0.01^{\mathrm{c}}$ & $0.64 \pm 0.02$ \\
& SEM & 0.01 & 0.01 \\
\hline Huinchalssalbori & 95 & $4.09 \pm 0.01^{\mathrm{a}}$ & $0.67 \pm 0.01^{\mathrm{a}}$ \\
& 75 & $3.92 \pm .0 .01^{\mathrm{b}}$ & $0.65 \pm 0.01^{\mathrm{ab}}$ \\
& SEM & $3.85 \pm 0.01^{\mathrm{c}}$ & $0.64 \pm 0.01^{\mathrm{b}}$ \\
& & 0.01 & 0.01 \\
\hline
\end{tabular}

${ }^{1)}$ Standard error of the means $(\mathrm{n}=9)$.

${ }^{2) a c}$ Values with different letters within the same column differ significantly $(p<0.05)$. 
가 $0.64 \pm 0.01 \sim 0.67 \pm 0.01 \%$ 를 나타냈으며(Table 4), 모든 시 료에서 도정률이 감소할수록 감소하는 경향을 보였으나 흰찰쌀보리에서만 유의적인 차이를 보였다. Park 등(6)은 보리 도정률 감소에 따라 총산도가 감소한다고 하여 본 연구결과와 같은 결과를 나타내었다.

\section{환원당 측정}

환원당은 산미, 감칠맛 등과 조화되어 막걸리의 독특한 맛에 기여하는 성분으로(21) 알코올 발효의 기질로 이용되 며 감미도에 영향을 주는 중요한 성분이다(22).

품종별로 도정률을 다르게 제조한 막걸리의 환원당 함량 의 변화는 Table 5 와 같다. 도정률이 $95 \%, 85 \%$ 및 $75 \%$ 로 감소됨에 따라 새쌀보리, 새찰쌀보리 및 흰찰쌀보리 막걸 리의 환원당 함량은 $9.43 \pm 0.34 ~ 11.63 \pm 0.78 \%, 7.93 \pm 0.0 .12$ $9.80 \pm 0.33 \%, 8.87 \pm 0.36 \sim 11.53 \pm 0.24 \%$ 로 나타났다. 또한 $95 \%$ 도정률에 비해 도정률이 $85 \%, 75 \%$ 로 감소됨에 따라 새쌀보리, 새찰쌀보리 및 흰찰쌀보리의 환원당 함량이 각 각 1.13 1.23, 1.12 1.24, 1.15 1.30배 더 높게 나타났다. 새 쌀보리, 새찰쌀보리 및 흰찰쌀보리 원료곡의 환원당 함량 은 4.38 $\pm 0.17 \sim 4.79 \pm 0.10 \%, 4.70 \pm 0.04 \sim 4.98 \pm 0.06 \%$ 및 $3.78 \pm$ $0.03 \sim 4.71 \pm 0.03 \%$ 로 도정률이 감소함에 따라 그 함량이 증 가하였다(data not shown). Lee 등(5)의 보고에 따르면 전분 질 원료를 달리한 입국 막걸리의 환원당 함량은 가용성 고형분 함량과 연관성이 있는 결과가 나타났다고 하였으 며, 본 연구결과에서도 같은 결과를 나타냈다. 이는 상기 서술한 바와 같이 도정률 감소에 따라 내부 전분층의 비율 이 높아지면서 환원당함량에 관여하는 a-amylase 등(15)의 전분 가수분해 효소가 이용할 수 있는 기질이 더 많아져

Table 5. Reducing sugar contents of Makgeolli brewed from different barley cultivars with different milling recovery

\begin{tabular}{ccc}
\hline Barley variety & $\begin{array}{c}\text { Milling } \\
\text { recovery }(\%)\end{array}$ & Reduing sugar (\%) \\
\hline \multirow{3}{*}{ Saessalbori } & 95 & $9.43 \pm 0.34^{\mathrm{c} 2)}$ \\
& 85 & $10.63 \pm 0.16^{\mathrm{b}}$ \\
& 75 & $11.63 \pm 0.78^{\mathrm{a}}$ \\
& SEM $^{\mathrm{l})}$ & 0.40 \\
\hline Saechalssalbori & 95 & $7.93 \pm 0.12^{\mathrm{c}}$ \\
& 85 & $8.90 \pm 0.32^{\mathrm{b}}$ \\
& 75 & $9.80 \pm 0.33^{\mathrm{a}}$ \\
& SEM & 0.22 \\
\hline \multirow{3}{*}{ Huinchalssalbori } & 95 & $8.87 \pm 0.36^{\mathrm{c}}$ \\
& 85 & $10.23 \pm 0.17^{\mathrm{b}}$ \\
& 75 & $11.53 \pm 0.24^{\mathrm{a}}$ \\
& SEM & 0.22 \\
\hline
\end{tabular}

${ }^{1)}$ Standard error of the means $(\mathrm{n}=9)$.

${ }^{2) a-c}$ Values with different letters within the same column differ significantly $(\mathrm{p}<0.05)$.
가용성 고형분 함량 뿐 아니라 환원당 함량이 더 높아진 것으로 사료된다.

\section{관능평가}

보리의 품종 및 도정률에 따라 제조한 막걸리의 관능적 특성 평가 결과를 Table 6에 제시하였다. 전반적으로 새쌀 보리 품종이 가장 높은 점수를 받았으며, 도정률에 따라 새쌀보리, 새찰쌀보리, 흰찰쌀보리 막걸리의 기호도 점수 는 높은 수치를 나타내었으나 새쌀보리의 맛과 흰찰쌀보리 의 색에서만 유의적인 차이를 나타내었다.

이와 같은 결과는, 앞에 서술한 바와 같이 도정률이 낮을 수록 명도값이 증가하였고 환원당 및 고형분 함량이 높게 나타난 것에 기인하여, 색과 맛 항목에서 좋은 점수를 받은 것으로 사료된다. Lee 등(23)은 쌀 전분을 이용한 양조 특성 연구결과 전분의 강하점도가 높은 품종에서 관능검사 결과 기호도에서 높은 점수를 얻었다고 발표한 바 있다. 이는 보리막걸리의 원료의 호화특성 분석결과와 일치하였다. 또 한 Chen 등(24)의 연구에 의하면 원료곡 내 탄수화물 함량 이 많을수록 a-amylase 효소활성에 환원당과 당 함량이 증 가한다고 발표하였으며, 이는 도정률이 증가함에 따라 탄 수화물의 증가로 인해 효소가 이용할 수 있는 기질이 많아 지므로 막걸리 맛에 영향을 미치는 것으로 판단된다. 따라 서 본 연구 결과, 보리의 품종 및 도정률에 따라 막걸리의 향기, 맛, 색상 등 품질 특성에 영향을 미치는 것으로 확인되 었다.

Table 6. Sensory characteristics of Makgeolli brewed from different barley cultivars with different milling recovery

\begin{tabular}{ccccc}
\hline Barley variety & $\begin{array}{c}\text { Milling } \\
\text { recovery (\%) }\end{array}$ & Color & Flavor & Taste \\
\hline & 95 & $4.50 \pm 1.03$ & $4.19 \pm 1.11$ & $3.31 \pm 1.20^{\mathrm{b} 2)}$ \\
Saessalbori & 85 & $4.81 \pm 1.22$ & $4.44 \pm 1.31$ & $3.94 \pm 1.39^{\mathrm{ab}}$ \\
& 75 & $5.13 \pm 1.15$ & $4.81 \pm 1.52$ & $4.63 \pm 1.75^{\mathrm{a}}$ \\
& SEM & 0.40 & 0.47 & 0.52 \\
\hline \multirow{5}{*}{ Saechalssalbori } & 95 & $4.25 \pm 1.57$ & $4.00 \pm 1.10$ & $3.63 \pm 1.59$ \\
& 75 & $4.56 \pm 1.36$ & $4.63 \pm 1.41$ & $3.88 \pm 1.20$ \\
& SEM & $4.94 \pm 0.93$ & $4.63 \pm 1.36$ & $3.69 \pm 1.20$ \\
& 95 & $4.06 \pm 1.12^{\mathrm{b}}$ & $4.00 \pm 1.21$ & $3.75 \pm 1.65$ \\
& 85 & $4.75 \pm 1.18^{\mathrm{ab}}$ & $4.38 \pm 1.36$ & $4.06 \pm 1.44$ \\
Huinchalssalbori & 75 & $5.06 \pm 1.12^{\mathrm{a}}$ & $4.69 \pm 1.14$ & $4.06 \pm 1.18$ \\
& SEM & 0.40 & 0.44 & 0.51 \\
\hline
\end{tabular}

${ }^{1)}$ Standard error of the means $(\mathrm{n}=20)$.

2)a,b Values with different letters within the same column differ significantly $(\mathrm{p}<0.05)$. 


\section{요 약}

본 연구에서는 보리 품종 및 도정률이 막걸리 품질특성 에 미치는 영향을 살펴보기 위해 도정률 $(95,85,75 \%)$ 을 달리한 새쌀보리, 새찰쌀보리, 흰찰쌀보리 원료의 특성을 살펴보고 이를 이용하여 제조한 막걸리의 품질특성을 살펴 보았다.

원료곡의 품질 특성은 도정률이 감소할수록 단백질, 지 방 및 회분 함량이 감소하는 경향을 나타내었으며 호화특성 또한 도정률이 감소할수록 유의적 $(\mathrm{p}<0.05)$ 으로 높은 경향 을 나타내었다. 일반적으로 호화 특성 측정 결과 최고점도 및 강하점도가 높고 치반점도가 낮으면 식미가 양호하게 되는데 본 연구에서는 새쌀보리 및 흰찰쌀보리가 새찰쌀보 리에 비해 식미특성이 양호할 것으로 판단된다. 보리의 품 종 및 도정률에 따라 제조한 막걸리의 알코올 함량과 총산 도의 유의한 차이는 없었으나, 도정률이 감소할수록 고형 분 함량과 환원당함량이 유의적 $(\mathrm{p}<0.05)$ 으로 증가하였으 며, 관능 특성을 살펴본 결과 보리의 품종과 도정률이 낮을 수록 막걸리의 향기, 맛, 색의 점수가 증가하는 것으로 나타 났다. 또한 고형분 함량, 환원당함량 그리고 관능적 특성에 서 새쌀보리로 제조된 막걸리에서 다른 품종에 비해 높은 수치를 확인할 수 있었다. 따라서 본 연구결과, 도정률이 75\%인 새쌀보리로 막걸리를 제조하였을 때 우수한 품질특 성을 갖는 막걸리를 기대할 수 있을 것으로 판단된다.

\section{감사의 글}

본 논문은 농촌진흥청 AGENDA 연구사업(과제번 호:PJ011337022016)의 지원에 의해 이루어진 것임.

\section{References}

1. Seog HM (2010) Physicochemical characterization of barley. Food Culture, 3, 302-305

2. Kim JH, Lee YT (2004) Effects of barley bran on the quality of sugar-snap cookie and muffin. J Korean Soc Food Sci Nutr, 33, 1367-1372

3. Kim GM, Jung WJ, Shin JH, Kang MJ, Sung NJ (2011) Preparation and quality characteristics of Makgeolli made with black garlic extract and Sulgidduk J Korean Soc Food Sci Nutr, 40, 759-766

4. Woo SM, Shin JS, Seong JH, Yeo SH, Choi JH, Kim TY, Jeong YJ (2010) Quality characteristics of brown rice Takju by different Nuruks. J Korean Soc Food Sci Nutr, 39, 301-307
5. Lee HS, Park YS, Bai DH (2014) Quality characteristics of Makgeolli (rice wine) fermented with Koji by starch types. Food Eng Prog, 18, 215-221

6. Park HY, Choi ID, Oh SK, Woo KS, Yoon SD, Kim HJ, Sim EY, Jeong ST (2015) Effects of different cultivars and milling degrees on quality characteristics of barley Makgeolli. J Korean Soc Food Sci Nutr, 44, 1839-1846

7. Lee YJ, Yi HC, Hwang KT, Kim DH, Kim HJ, Jung CM, Choi YH (2012) The qualities of Makgeolli (Korean rice wine) made with different rice cultivars, milling degrees of rice, and Nuruks. J Korean Soc Food Sci Nutr, 41, 1785-1791

8. Chun AR, Kim DJ, Yoon MR, Oh SK, Choi IS, Hong HC, Kim YG (2012) Effect of milling degree on the physicochemical and sensory quality of Sogokju. J Korean Soc Food Sci Nutr, 41, 136-142

9. Kim SR, Ahn JY, Lee HY, Ha TY (2004) Various properties and phenolic acid contents of rices and rice brans with different milling fractions. Korean J Food Sci Technol, 36, 930-936

10. Kim KA, Jeon ER (1996) Physicochemical properties and hydration of rice on various polishing degrees. Korean J Food Sci Technol, 28, 959-964

11. Kim HR, Lee AR, Kwon YH, Lee HJ, Jo SJ, Kim JH, Ahn BH (2010) Physicochemical characteristics and volatile compounds of glutinous rice wines depending on the milling degrees. Korean J Food Sci Technol, 42, 75-81

12. Kim DJ, Oh SK, Lee JH, Yoon MR, Choi IS, Lee DH, Kim YG (2012) Changes in quality properties of brown rice after germination. Korean J Food Sci Technol, 44, 300-305

13. Lee MS, Lee KE, Jong SG, Lee HB (2015) Relationships of amylogram characteristics and table quality in waxy corn kernel. Korean J Crop Sci, 60, 470-474

14. Choi JH, Jeon JA, Jung ST, Park JH, Park SY, Lee CH, Kim TJ, Choi HS, Yeo SH (2011) Quality characteristics of Seoktanju fermented by using different commercial Nuruks. Korean J Microbial Biotechnol, 39, 56-62

15. Jin TY, Kim ES, Eun JB, Wang SJ, Wang MH (2007) Changes in physicochemical and sensory characteristics of rice wine, Yakju prepared with differenr amount of red yeast rice. Korean J Food Sci Technol, 39, 309-314

16. Park JH, Choi JH, Yeo SH, Jeong ST, Choi HS, Kang JE, Kim SR (2013) A study on the quality characteristics of Makgeolli using heat treatment of traditional Korean Nuruk extract. J East Asian Soc Dietary Life, 23, 620-628 
17. Song JC, Park HJ, Shin WC (1997) Change of Takju qualities by addition of cyclodextrin during the brewing and aging. Korean J Food Sci Technol, 29, 895-900

18. Kim JY, Sung KW, Bae HW, Yi YH (2007) pH, acidity, color, reducing sugar, total sugar, alcohol and organoleptic charateristics of puffed rice powder added Takju during fermentation. Korean J Food Sci Technol, 39, 266-271

19. Baek CH, Choi JH, Choi HS, Jeong ST, Kim JH, Jeong YJ, Yeo SH (2013) Quality characteristics of brown rice Makgeolli produced under differing conditions. Korean J Microbiol Biotechnol, 41, 168-175

20. Lee SB, Ko GH, Yang JY, Oh SH (2001) Food fermentation. Hyoil publishing Co, Seoul, Korea, $p$ $217-218$
21. Lee SM, Lee TS (2000) Effect of roasted rice and defatted soybean on the quality characteristics of Takju during fermentation. J Natural Sci, 12, 71-79

22. Park CS, Lee TS (2002) Quality characteristic of Takju prepared by wheat flour Nuruk Korean J Food Sci Technol, 34, 296-302

23. Lee DH, Lee YS, Cho CH, Seo JS, Park IT, Kim HD, Lim JW (2013) Brewing and fermenting characteristics of Makgeolli produced from high-yielding rice varieties. Korean J Food Sci Technol, 45, 714-720

24. Chen Y, Hwang J, Chang YH (2013) Quality characteristics of Makgeolli added with red bean. Korean J Food Cook Sci, 29, 774-784 